\title{
Leadership development of nursing students in a material and sterilization center
}

\author{
Desenvolvimento de liderança de acadêmicos de enfermagem \\ em um centro de material e esterilização \\ Desarrollo de liderazgo de estudiantes de enfermería \\ en un centro de material y esterilización
}

\author{
Crislaine Pires Padilha Paim ${ }^{\mathrm{a}}$ \\ Ana Karina da Silva Rocha Tanaka ${ }^{b}$ \\ Daniela Silva dos Santos Schneider ${ }^{a}$ \\ Sara Satie Yamamoto ${ }^{a}$ \\ Rafael Rambo ${ }^{c}$ \\ Bernarda Cassaro ${ }^{d}$
}

\begin{abstract}
How to cite this article: Paim CPP, Tanaka AKSR, Schneider DSS, Yamamoto SS, Rambo R, Cassaro B. Leadership development of nursing students in a material and sterilization center. Rev Gaúcha Enferm. 2021;42(spe):e20200202. doi: https://doi.org/10.1590/19831447.2021.20200202
\end{abstract}

Hospital de Clínicas de Porto Alegre (HCPA), Serviço de Enfermagem em Centro Cirúrgico, Centro de Materiais e Esterilização. Porto Alegre, Rio Grande do Sul, Brasil.

- Universidade Federal do Rio Grande do Su (UFRGS), Escola de Enfermagem, Departamento de Enfermagem Médico-Cirúrgica. Porto Alegre, Rio Grande do Sul, Brasil

Universidade Federal do Rio Grande do Sul (UFRGS), Escola de Enfermagem, Curso de Graduação em Enfermagem. Porto Alegre, Rio Grande do Sul, Brasil.

d Universidade do Estado de Santa Catarina (UDESC), Escola de Enfermagem, Curso de Graduação em Enfermagem. Chapecó, Santa Catarina, Brasil.

\section{ABSTRACT}

Objective: To analyze the experiences of Nursing students during the mandatory hospital internship at a Material and Sterilization Center with a focus on leadership development.

Method: This is an experience report of a mandatory hospital curricular internship anchored in the national curricular guidelines for Nursing, of a descriptive-reflective nature, and carried out in a general university hospital in southern Brazil, from March to June 2019. Results: Activities were developed in order to develop leadership aspects such as people, orthotics and prosthetics management, surgical planning, conflict management, and assertive communication.

Final considerations: The mandatory hospital curricular internship at the Material and Sterilization Center favored the students in the leadership process, management, decision-making, and development of autonomy for leading nurses.

Keywords: Sterilization. Education, nursing. Leadership. Students, nursing.

\section{RESUMO}

Objetivo: Analisar as vivências de acadêmicos de enfermagem durante o estágio curricular obrigatório hospitalar em um Centro de Material e Esterilização com foco no desenvolvimento de liderança.

Método: Trata-se de um relato de experiência de estágio curricular obrigatório hospitalar ancorado nas diretrizes curriculares nacionais para a enfermagem, de cunho descritivo-reflexivo, realizado em um hospital geral universitário no sul do Brasil, no período de março à junho de 2019.

Resultados: Foram desenvolvidas atividades que proporcionaram o desenvolvimento de aspectos de liderança como gestão de pessoas, gestão de órteses e próteses, do planejamento cirúrgico, da gestão de conflitos e comunicação assertiva.

Considerações finais: 0 estágio curricular obrigatório hospitalar em Centro de Materiais e Esterilização favoreceu aos estudantes 0 processo de liderança, a gestão, a tomada de decisão e desenvolvimento da autonomia de enfermeiros líderes. Palavras-chave: Esterilização. Educação em enfermagem. Liderança. Estudantes de enfermagem.

\section{RESUMEN}

Objetivo: Analizar las experiencias de los estudiantes de enfermería durante el internado hospitalario obligatorio en un Centro de Material y Esterilización con enfoque en el desarrollo del liderazgo.

Método: Se trata de un relato de experiencia de internado curricular hospitalario obligatorio anclado en los lineamientos curriculares nacionales de enfermería, de carácter descriptivo-reflexivo, realizado en un hospital universitario general del sur de Brasil, de marzo a junio de 2019

Resultados: Se desarrollaron actividades que brindaron el desarrollo de aspectos de liderazgo como el manejo de personas, manejo de ortesis y prótesis, planificación quirúrgica, manejo de conflictos y comunicación asertiva.

Consideraciones finales: La internación curricular hospitalaria obligatoria en el Centro de Materiales y Esterilización favoreció a los estudiantes en el proceso de liderazgo, gestión, toma de decisiones y desarrollo de la autonomía por parte de enfermeras líderes. Palabras clave: Esterilización. Educación en enfermería. Liderazgo. Estudiantes de enfermería. 


\section{口INTRODUCTION}

The reflection on the challenges of leadership development in the training process has been the subject of discussions in Nursing, considering that the National Curricular Guidelines for Nursing (Diretrizes Curriculares Nacionais para a Enfermagem, DCN/ENF) ${ }^{(1-2)}$ contain elements that report on an innovative teaching-learning process, in that they recommend a critical, reflective and creative view of learning, in which the students are considered active subjects in this process. A context in which the act of leading represents a managerial competence, through which the students seek to influence and motivate the team in which they are inserted to achieve objectives and goals that favor meeting the health demands, requesting students able to be entrepreneurs, managers and leaders of Nursing and health teams ${ }^{(3)}$. In this way, anchored in the DCN-ENF as a national policy document that regulates the type of curriculum and training that Nursing professionals should receive in the country, leadership has as guiding elements that the students need to develop relational skills that will facilitate conflict management, management of people and of material supplies, as well as the clinical and managerial decision-making process ${ }^{(4)}$. Therefore, it is necessary to encourage the development of leadership also during the training process, so that the future nurses can be more secure and able to exercise it.

In compliance with the DCN-ENF, the curricular content of leadership requires to be put into practice by means of theoretical, theoretical-practical and practical activities, as well as by means of mandatory curricular internships, giving the future nurse the professional capacity to meet the demands and prevalent and priority needs of the population, according to the epidemiological reality of the region and the country, in line with the public policies. In other words, it is an essential skill for interpersonal relationships and teamwork, which must result in the students' motivation at the individual and collective levels to assume leadership positions with commitment, responsibility, talent, empathy, and ability to make decisions, communicate and manage in an effective and efficient way ${ }^{(1-2)}$.

The mandatory curricular internships are part of the curricular structure of the Nursing courses and are intended to improve the student's skills and competences through performance supervised by undergraduate Nursing professors and nurse professionals in the scenarios of the Unified Health System (Sistema Único de Saúde, SUS), allowing the students to know and experience health care situations and public policies in varied life situations, as well as those related to organization of the current health system and to inter-professional and multidisciplinary teamwork, for which they will have to assume full responsibility when graduating. Thus, they constitute the supervised practices culminating in professional training. In addition, it must correspond to at least $20 \%$ of the total workload of the Bachelor of Nursing Course ${ }^{(1-2)}$

A number of studies point out the mandatory hospital curricular internship as one of the fundamental elements in academic training, as it allows the student to experience and direct real situations with logical reasoning and critical thinking ${ }^{(5-7)}$.

However, for leadership learning to take place in the mandatory hospital curricular internship, some potentialities must be worked on in the health services, such as transversal teaching of leadership ${ }^{(8)}$, strengthening of the articulation between teaching institutions and health services ${ }^{(5-6)}$, greater investment in permanent education of teachers and professionals ${ }^{(6)}$, considering the knowledge and experience of the students ${ }^{(9)}$, and also valuing the leadership skills of both professionals and students $s^{(8,10)}$.

Actions for the recognition and appreciation of the exercise of leadership in the training process of nurse leaders ${ }^{(10)}$ are the action object of the Nursing Now global campaign, under the motto "Where there is life, there is Nursing". The main objective of the campaign is to strengthen the education and development of the Nursing professionals aiming at leadership, in addition to improving the working conditions, sharing successful and innovative practices based on scientific evidence at the national and regional levels $s^{(11-12)}$.

The campaign makes us reflect on possible care spaces, being urgent to provide learning scenarios and situations that enable the development of leadership by the students in training, with different experiences. In general, a tendency for the students to choose places that offer direct care to the patient is perceived ${ }^{(8)}$, and this is mainly due to the concern to acquire skills in the realization of techniques; they leave aside the important knowledge of the specific managerial processes of some support areas at this training moment, in which it is intended to train innovative nurses able to transform reality with ethics and commitment ${ }^{(1-2)}$.

A Material and Sterilization Center (Centro de Materiais e Esterilização, CME), a support area directly involved with new technologies of medical equipment and devices that imply team management and process organization, can be an alternative of an internship location that offers training of critical and reflective nurses, inserted in a historical-social context, guided by ethical principles, and able to intervene in the population's health problems/situations/Nursing work processes/care technologies required ${ }^{(13-14)}$.

Considering the above, the guiding question of the study was "How do Nursing students experience leadership 
learning in the mandatory curricular internship at a Material and Sterilization Center?" The objective of the study was to analyze the experiences of Nursing students during the mandatory curricular internship in hospital care at a Material and Sterilization Center, with a focus on leadership development.

\section{METHODOLOGY}

This is an experience report of a descriptive-reflective nature, with a focus on situations that strengthened the problematization or consolidation of knowledge from the leadership experiences of two students from the undergraduate Nursing course, monitored by a guiding professor and by two supervising nurses during the internship. The mandatory hospital curricular internship took place in the CME of a general university hospital in southern Brazil, from March to June 2019, in the tenth stage of 10 semesters of the course, covering a total workload of 418 hours.

The study field hospital has capacity to serve 831 hospital beds and 29 operating rooms, in addition to a large outpatient network and support areas. The CME is part of the Nursing Service in the Surgical Center and performs the processing of non-critical, semi-critical and critical health products of complex and non-complex conformation ${ }^{(15)}$ of the entire institution, its mean production being 80,000 packages per month.

The team responsible for processing materials in this $\mathrm{CME}$ is composed of 74 professionals among nursing assistants and technicians, nine nurses (eight assistants and a unit coordinator), in addition to an administrative assistant. The sector works 24 hours a day, seven days a week.

The experiences were analyzed according to the internship observations and reports included in the field diary by the students. For being a documentary analysis, it was not necessary to prepare the Free and Informed Consent Form (FICF). However, there was the consent of the legal guardians for the documents analyzed and the ethical precepts were respected.

\section{$\square$ RESULTS AND DISCUSSION}

The analysis of the notes of academic experiences during the mandatory curricular internship in the CME brought greater visibility to the actions that contribute to the empowerment of the leadership training process by the future professional nurse, considering the assumptions of the Nursing Now Campaign ${ }^{(11-12) .}$
In the daily records taken down by the students in the stage experienced, their gradual maturation on the Nursing practice in a CME was perceived, bringing reflections and criticism in the notes in the field diary. They also endeavored to review concepts and the minuteness of knowledge in the CME, having activity plans based on themes listed by RDC ANVISA No. 15/2012 $2^{(15)}$, required as minimum qualification of the professionals working in this specific area.

Acting with knowledge in the CME was important to develop leadership in the students. In their records, they tell how the social skills base was elaborated for the development of the common team objective, in the $\mathrm{CME}^{(3)}$ : offering the patients a health product in safe use conditions.

Regarding the students, how could they positively influence their team in pursuit of this common objective? In addition, they would also be strengthening teamwork skills at a time when they were improving their management view and personal skills in appropriating behavioral values in the $\mathrm{CME}^{(3)}$.

Thus, meaningful learning started to guide the mandatory hospital curricular internship, having as methodological principles interdisciplinary mastery of knowledge, integrality of training, and inter-professionality of the practices and of work in health ${ }^{(1-2)}$. The main actions performed by the students in the mandatory hospital curricular internship are detailed below.

In the reception and cleaning sector, activities related to the following were developed: reception, separation and disassembly, cleaning, disinfection of the ventilatory assistance materials, cleaning inspection, and analysis and recall of materials that failed the material inspection. Performing these activities made it possible to understand the dynamics, workflow and development process of decision-making in the analysis of processes and managerial development of the stages, in addition to the insertion of the students in this area.

Regarding the control of orthotics, prosthetics and special materials (OPSM), the following actions were developed: reception, checking, registration, debit auditing activities, and needs to manage replacement and/or communication of use after surgery and return. In this way, the students applied assertive communication and feedback in relation to the assistance process developed by the Nursing team ${ }^{(10)}$, in addition to experiencing notions of critical thinking and decision-making in surgical planning.

In the area of material preparation, activities were developed related to the reception of the materials from the cleaning area, drying of the materials, separation, inspection, 
lubrication and functionality test of the surgical instruments, checking and assembly, packaging and conditioning of the materials. From the operational activity, it was possible to expand the systemic view of the institution, improving the process of managing priorities based on surgical planning and the profile of institutional care.

In the sterilization area, activities referring to the assembly and critical analysis related to the quality of this activity were developed, monitoring and understanding of the sterilization cycle, in addition to evaluating the effectiveness of the process.

In the area of storage and distribution of materials and sterile clothing, they developed activities related to stock management and emergency surgery demands, organization, control of the environment, and critical analysis of the stock to support decision-making in relation to the priorities and guidelines for the CME teams.

In addition, the participation of the students in management activities was made possible so that they exercised leadership in the Nursing teams, since it is by doing so that they could gradually realize the dimension of the complexity of the $\mathrm{CME}$, of the workforce, and of the risks with patient safety, in order to exercise mastery of the knowledge ${ }^{(3)}$. Thus, they worked in the sizing of scales, in work meetings, in Nursing and inter-professional teamwork, and in conflict management, as well as they integrated permanent education in health activities with a focus on improving assertive communication.

It is also noteworthy that the possibility of experiencing protocols and assistance flows in the routine of the CME allowed the students to plan care actions and risk management in the assistance provided together with the team. Also, by experiencing the day-to-day challenges of a $\mathrm{CME}_{\text {, }}$ they were able to reinvent themselves in the application of knowledge, skills and attitudes required to strengthen their training and professional identity.

The students reported the experience in this internship field as being challenging, since it required knowledge focused both on the management and processing of health products, a gap which was filled day by day in the internship.

With regard to the factors that positively influenced leadership development in the insertion of the students in the $\mathrm{CME}$, the confidence and sense of belonging to the team that emerged with the progress of the internship stand out. The students showed responsibility and ethical commitment, gradually assuming leadership of the Nursing team ${ }^{(3,9)}$.

Regarding the challenges for leadership development in the insertion of the students, the difficulties of personal relationships and initial integration with the team were described, perceived at the beginning of the internship. It is noteworthy that the articulation of the Nursing team and interns is complex, implying moments of mutual learning and cooperation and in situations of heterogeneous unrest. However, these difficulties were overcome in the first two weeks of the curricular internship, as the insertion in the practice and the offer of different learning scenarios allowed the students to exercise leadership in the Nursing team in which they were inserted. This corroborates a study ${ }^{(9)}$ which points out that the factors involved in the activities of the curricular internship related to the leadership process are mainly related to adversities of acceptance by the team as well as to interpersonal relationships and communication issues.

There were times when the students positioned themselves within a reflection process which, for being interning in a university hospital, they hoped to find a more flexible team, given that one of its objectives is to be a learning scenario for the training of health professionals. The importance of the practice was also due to the meaning attributed to the competence of the teacher guidance, integrating teaching/service. Therefore, leadership learning necessarily took place in concrete and contextualized situations, highlighting the importance of issues such as phlegm, empathy, communication, and congruence with a view to facilitating the practice ${ }^{(16)}$.

Leading in Nursing means being prepared to frequently work with diversity and setbacks, and serenity is necessary to keep listening and the communication process assertive and effective, as people impress their individuality in what they do. When the first leadership difficulties emerged, this was ratified by the students, attributing reflections and criticality to learning, becoming the focus of the actions, preparing them as leaders in innovation, creativity and sensitivity ${ }^{(9)}$. Thus, a reciprocal teaching-learning process was established, strengthening both professionals and students in an ongoing teaching/service relationship ${ }^{(5-6)}$

\section{FINAL CONSIDERATIONS}

The mandatory hospital curricular internship in the Material and Sterilization Center favored the development in the process of leadership, management, decision-making and autonomy. Thus, experiences are outlined based on the curricular guidelines that reinforce the integration between theory and practice, interdisciplinary training, the guarantee of participation by the service nurses in the practical activities and in the mandatory curricular 
internship, taking place in a professional training process for leading nurses.

By articulating teaching and learning, by knowing, classifying, analyzing, discussing, expressing opinions, making analogies, registering, making diagnoses, and making generalizations, among others, the mandatory hospital curricular internship established dexterities that turned the achievement of autonomy, discernment and proactivity of the students as leaders into quite singular aspects, as well as to ensure the quality and safety of the work processes of a Material and Sterilization Center, for comprehensive health care of people and collectives.

In relation to the nurse's exclusive activities, the students experienced the coordination of the unit's work process, allowing for the development of leadership in people management, orthotics/prosthetics/special materials management, surgical planning, conflict management, and assertive communication.

The importance of the teaching/service integration in the development of the mandatory hospital curricular internship is highlighted, as described by the students, favoring interpersonal relationships, allowing them the ability to develop criticality, to be resolute and able to make decisions, essential elements for leadership performance, preparing them for the work field. Developing the potential for leadership during academic training left motivating feelings of belonging to the team and the institution in the students, shared by teachers and Nursing and health teams inserted in the practice.

The study contributions are related to encouraging the mandatory hospital curricular internship in a Material and Sterilization Center so that the students can, in addition to expanding their theoretical and practical knowledge, exercise their leadership potential. The limitations refer to the perception in a single internship location. Therefore, new research studies in different types of institutions would be important in order to rethink teaching strategies to develop the necessary skills for putting that competence into practice in such a specific field.

\section{REFERENCES}

1. Ministério da Educação (BR). Conselho Nacional de Educação. Câmara de Educação Superior. Resolução nº 3, CNE/CES, de 7 de novembro de 2001. Institui diretrizes curriculares nacionais do curso de graduação em enfermagem. Diário Oficial da União. 2001 nov 9 [cited 2020 Jul 27];138(215 Seção1):37-8. Available from: https://pesquisa.in.gov.br/imprensa/jsp/visualiza/index. jsp?data=09/11/2001\&jornal=1\&pagina=37\&totalArquivos=160
2. Ministério da Saúde (BR). Conselho Nacional de Saúde. Resolução № 573, de 31 de janeiro de 2018. Recomendações do Conselho Nacional de Saúde à proposta de Diretrizes Curriculares Nacionais (DCN) do curso de graduação Bacharelado em Enfermagem. Diário Oficial da União. 2018 nov 06 [cited 2020 Jul 27];155(213 Seção 1):38-42. Available from: $\quad$ https://pesquisa.in.gov.br/imprensa/jsp/visualiza/index. jsp?data $=06 / 11 / 2018 \&$ jornal $=515 \&$ pagina $=39 \&$ total Arquivos $=83$

3. Miles JM, Scott ES. A new leadership development model for nursing education. J Prof Nurs. 2019;35(1):5-11. doi: https://doi.org/10.1016/j. profnurs.2018.09.009

4. Amestoy SC, Trindade LL, Silva GTR, Santos BP, Reis VRSS, Ferreira VB. Leadership in nursing: from teaching to practice in a hospital environment. Esc Anna Nery. 2017;21(4):e20160276. doi: https://doi. org/10.1590/2177-9465-ean-2016-0276

5. Baldoino AS, Veras RM. Analysis of service-learning activities adopted in health courses of Federal University of Bahia. Rev Esc Enferm USP. 2016 jun;50(esp):17-24. doi: https://doi.org/10.1590/ S0080-623420160000300003

6. Tonhom SFR, Moraes MAA, Pinheiro OL. Nurse's training centred on professional practice: perception of students and professors. Rev Gaúcha Enferm. 2016;37(4):e63782. doi: https://doi. org/10.1590/1983-1447.2016.04.63782

7. Esteves LSF, Cunha ICKO, Bohomol E, Negri EC. Supervised internship in undergraduate education in nursing: integrative review. Rev Bras Enferm. 2018;71(suppl.4): 1740-50. doi: https://doi. org/10.1590/0034-7167-2017-0340

8. Lins MDL, Balsanelli AP, Neves VR. Leadership teaching strategies in undergraduate nursing courses. Rev Rene. 2018;19:e3226. doi: https://doi. org/10.15253/2175-6783.2018193226

9. Knop ALK, Gama BMBM, Sanhudo NF. Nursing students and leadereship development challenges facing in the curriculum internship. Rev Enferm Cent-Oeste Min. 2017;7:e1378. Available from: http://www.seer.ufsj.edu.br/ index.php/recom/article/view/1378. doi: https://doi.org/10.19175/recom. v7i0.1378

10. Oliveira C, Santos LC, Andrade J, Domingos TS, Spiri WC. Leadership in the perspective of Family Health Strategy nurses. Rev Gaúcha Enferm. 2020;41:e20190106. doi: https://doi. org/10.1590/1983-1447.2020.20190106

11. Kennedy A. Wherever in the world you find nurses, you will find leaders. Rev Latino-am Enfermagem. 2019;27:e3181. doi: https://doi. org/10.1590/1518-8345.0000.3181

12. Cassiani SHB, Lira Neto JCG. Nursing perspectives and the "Nursing Now" Campaign. Rev Bras Enferm. 2018;71(5):2351-2. doi: https://doi. org/10.1590/0034-7167.2018710501

13. Ferreira EBF, Melo LSS, Souza EWF, Modesto BCM, Valença MP, Souza CFQ. Evaluation of academics on nursing teaching and learning in a material and sterilization center. Rev SOBECC. 2018:23(4):178-83. doi: https://doi. org/10.5327/Z1414-4425201800040004

14. Lucon SMR, Braccialli LAD, Pirolo SM, Munhoz CC. Training of nurses to work in the central sterile supply department nurse. Rev SOBECC. 2017;22(2):90-7. doi: https://doi.org/10.5327/Z1414-4425201700020006 
15. Agência Nacional de Vigilância Sanitária (BR). Resolução RDC no 15, de 15 de março de 2012. Dispõe sobre requisitos de boas práticas para 0 processamento de produtos para a saúde e dá outras providências. Diário Oficial da União. 2012 [cited 2020 May 20];149(54 Seção 1):43-6. Available from: https://pesquisa.in.gov.br/imprensa/jsp/visualiza/index. jsp?data $=19 / 03 / 2012 \&$ jornal $=1 \&$ pagina $=43 \&$ total Arquivos $=128$

\section{- Authorship contribution}

Conceptualization: Sara Satie Yamamoto.

Methodology: Crislaine Pires Padilha Paim, Ana Karina da Silva Rocha Tanaka.

Writing-original draft: Crislaine Pires Padilha Paim, Daniela Silva dos Santos Schneider, Rafael Rambo, Bernarda Cassaro.

Writing-review \& editing: Ana Karina da Silva Rocha Tanaka.

\section{- Corresponding author:}

Crislaine Pires Padilha Paim

E-mail: crislainep@hcpa.edu.br
16. Dall'Agnol CM, Oliveira AP, Cardoso ASF. Nursing management practicum: impact to the team in medical-surgical units. Rev Gaúcha Enferm. 2017;38(2):e61647. doi: https://doi.org/10.1590/1983-1447.2017.02.61647

\section{Associate editor:}

Dagmar Elaine Kaiser

Editor-in-chief:

Approved: 10.08.2020
Maria da Graça Oliveira Crossetti 